\title{
Effect of electrohydraulic and extracorporeal shock waves on gastrointestinal cancer cells and their response to cytotoxic agents
}

\author{
A Warlters, D L Morris, A Cameron-Strange, W Lynch
}

\begin{abstract}
Electrohydraulic and extracorporeal shock waves were used to treat the colorectal and gastric cancer cell lines LIM 2412 and MKN45. The effect on viability, cell proliferation, and the action of antitumour drugs was studied. Results showed that electrohydraulic and extracorporeal shock waves were cytotoxic to all cell lines and also caused considerable inhibition of cell proliferation. A significant additional reduction in cell viability was achieved by shock waves in cancer cells treated with methotrexate, 5-fluorouracil, and vincristine. These data indicate that shock waves may be worthy of further evaluation in the treatment of gastrointestinal cancers.
\end{abstract}

Despite continuing scientific research into the detection and treatment of gastrointestinal cancers, colon cancer remains the commonest cause of cancer deaths in non-smokers in many parts of the world: one in 25 Australians is expected to develop cancer of the bowel. ${ }^{1}$ There has been no major improvement in the overall five year survival rate in the last 40 years. ${ }^{2}$ The search for new treatments or methods of improving the results of existing therapy has included studies of chemosensitisation by temperature ${ }^{3}$ and radiotherapy.

In 1985, Russo et $a l^{5}$ first showed that high energy shock waves (HESW) suppressed tumour growth both in vitro and in vivo. Since then, several other groups have shown that HESW cause delayed cell growth and cell death in both normal and malignant cells in vitro..$^{6-7}$ The effect of HESW on gastrointestinal cancers has received little attention: however, a group in the UK have shown some effect in a gastric cancer cell line. ${ }^{8}$ We are investigating the response of the colonic cancer cell line LIM 2412, as well as the gastric carcinoma cell line, MKN45, to extracorporeal shock waves (ECSW) and electrohydraulic shock waves (EHSW).

These forms of shock waves have been shown to alter cell membrane permeability, expose DNA, and damage mitochondrial structures. ${ }^{9}$ The possible effect of HESW on the sensitivity of cancer cells to cytotoxic drugs may be by membrane damage, allowing higher intracellular drug concentrations, ${ }^{10}$ or by effects on intracellular organelles, " or a combination of these.

\section{Methods}

CELL CULTURE

LIM 2412, kindly donated by the Ludwig Insti- tute in Melbourne, and MKN45 were grown in RPMI supplemented with $10 \%$ fetal calf serum. All cell lines were kept in an incubator at $37^{\circ} \mathrm{C}$ with a $5 \% \mathrm{CO}_{2}$ humidifier. MKN45 was removed from tissue culture flasks using 0.025 trypsin/ ethylenediaminetetra-acetic acid (EDTA) solution; LIM 2412 is a suspension cell line, therefore trypsinising was not required.

\section{ELECTROHYDRAULIC SHOCK WAVES}

An ACMI electrohydraulic spark gap lithotriptor was used for generation of EHSW. The ACMI lithotriptor works by placing an endoscopic electrode beneath the surface of an electrolyte solution and discharging an electrical spark. This spark results in the dielectric breakdown of water in the area of the probe, which generates an initial shock wave and a gas bubble. When the initiation bubble collapses, a second pressure wave is produced."

Cells were placed in a polyurethane tube and allowed to form a pellet. A 5 Fr probe was placed just below the surface of the culture fluid (this was found to contain sufficient electrolytes for shock wave generation) and cells received either $0,1,10$, or 20 shocks at $150 \mathrm{~V}$.

\section{EXTRACORPOREAL SHOCK WAVES}

In the Dornier system, ECSW are also generated by an underwater spark discharge. The discharging electrode is positioned in the focus of a rotationally symmetric semi-ellipsoid. ${ }^{12}$ A Dornier HM3 spark gap lithotriptor in the Lithotripsy Unit at Prince Henry Hospital was used for ECSW treatment.

MKN45 and LIM 2412 cells were placed in three polyethylene tubes and labelled 'control', 'radiation control,' and 'sample.' MKN45 cells received either 0,500 , or 1500 shocks at $18 \mathrm{kV}$, while 2412 cells were exposed to 0,100 , or 1000 shocks at $18 \mathrm{kV}$. MKN45 cells were exposed to higher shock wave numbers as they seemed to be less sensitive to EHSW. The ideal ECSW dose to achieve cell death is unknown. Radiation control was placed outside the focus of the shock wave but in the area of radiation exposure.

VIABILITY ASSAYS

$1 \times 10^{5}$ EHSW and ECSW treated cells were aliquoted into 96 well microtitre plates. Fifty $\mu \mathrm{l}$ of either 5-fluorouracil (5-FU), methotrexate (MTX), or vincristine (VCR) were then added to each group of treated cells. A range of antitumour drug concentrations was used $-5-\mathrm{FU}, 0-1 \mathrm{mg} /$ $\mathrm{ml}$; MTX, 0-10 mg/ml; and VCR, 0-19 $\mu \mathrm{g} / \mathrm{ml}$. 
All experiments were performed in triplicate and viability was assessed using trypan blue exclusion after 24 and 72 hour incubations.

\section{PROLIFERATION ASSAYS}

$1 \times 10^{5}$ cells which had received either EHSW or ECSW treatment were aliquoted into 96 well microtitre plates. Fifty $\mu l$ of each drug, at the concentrations outlined above, were then added to each group of shocked cells. All experiments were done in triplicate. Plates were then incubated for 72 hours and cells were pulsed with tritiated thymidine $1 \mu \mathrm{Ci} /$ well for 18 hours.

After this, cells were harvested and counted on a beta counter. The percentage inhibition of control was calculated as follows:

$$
\% \text { Inhibition }=1 \times \frac{\text { DPM sample }}{\text { DPM control }} \times 100
$$

\section{STATISTICAL TESTS}

A two way ANOVA was done on viability data to assess significance.

Statistical significance of proliferation assays was determined by the proportional difference of means using Student's $t$ test.

\section{Results}

EFFECT OF EHSW ON CELL VIABILITY AND RESPONSE TO CYTOTOXIC AGENTS

EHSW significantly reduced cell viability in LIM2412 $(p<0.001)$ and MKN45 $(p<0.01)$ up to $40 \%$ and $10 \%$ respectively (Fig 1 ). An additional $10-20 \%(\mathrm{p}<0.05)$ reduction in LIM2412 viability was seen when 5-FU and VCR were present after HESW treatment, as shown in Table I.

There was little additional effect of 5-FU at concentrations higher than $0.1 \mathrm{mg} / \mathrm{ml}$ for both

Figure 1: Effect of electrohydraulic shock waves on MKN45 and LIM 2412 cell viability.
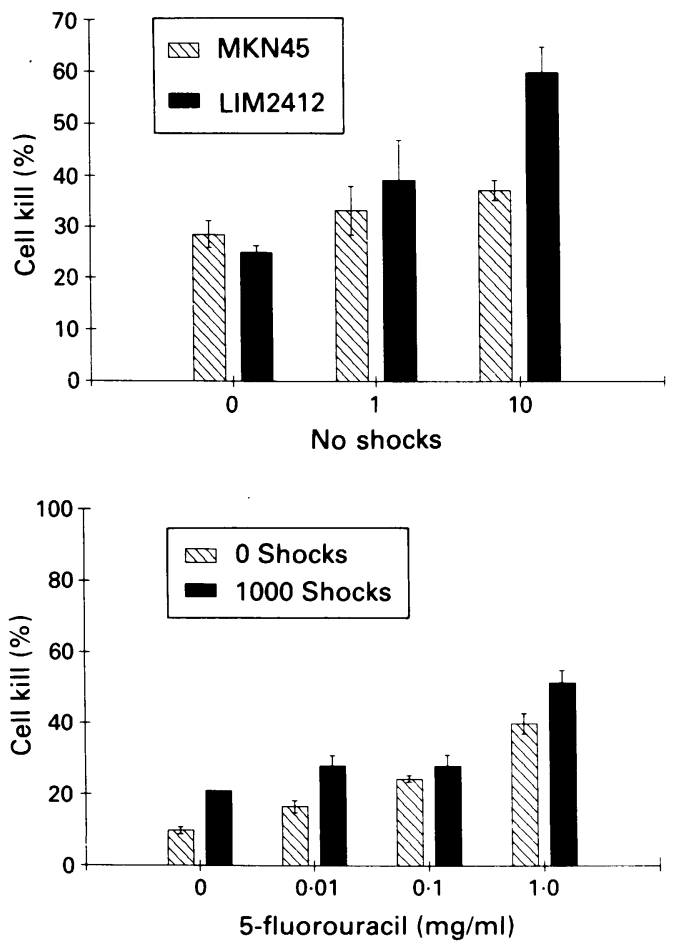

Response of MKN45 and LIM2412 to cytotoxic drugs after electrohydraulic shock wave treatment

\begin{tabular}{|c|c|c|c|c|}
\hline \multirow[b]{2}{*}{ Drug } & \multirow[b]{2}{*}{ Cell line } & \multicolumn{3}{|c|}{$\begin{array}{l}\text { Percentage viable cells } \\
\text { No of shocks }\end{array}$} \\
\hline & & 0 & 1 & 10 \\
\hline \multicolumn{5}{|c|}{ 5-fluorouracil ( $\mathrm{mg} / \mathrm{ml})$ : } \\
\hline 0 & LIM 2412 & $75(1 \%)$ & $61(6 \%)$ & $40(4 \%)$ \\
\hline $0 \cdot 1$ & $"$ & $45(9 \%)$ & $49(7 \%)$ & $47(5 \%)$ \\
\hline $1 \cdot 0$ & $"$ & $56(4 \%)$ & $37(3 \%)$ & $30(2 \%)$ \\
\hline \multicolumn{5}{|c|}{ Vincristine $(\mu \mathrm{g} / \mathrm{ml})$ : } \\
\hline 0 & LIM2412 & $687 \%)$ & $45(5 \%)$ & $34(11 \%)$ \\
\hline $0 \cdot 1$ & & $49(7 \%)$ & $46(10 \%)$ & $37(7 \%)$ \\
\hline $10 \cdot 0$ & , & $35(16 \%)$ & $36(1 \%)$ & $25(8 \%)$ \\
\hline \multicolumn{5}{|c|}{ 5-fluorouracil $(\mathrm{mg} / \mathrm{ml})$ : } \\
\hline 0 & MKN45 & $35(1 \%)$ & $26(3 \%)$ & $25(4 \%)$ \\
\hline $0 \cdot 1$ & $"$ & $31(4 \%)$ & $20(1 \%)$ & $15(1 \%)$ \\
\hline $1 \cdot 0$ & $"$ & $28(7 \%)$ & $20(1 \%)$ & $18(2 \%)$ \\
\hline \multicolumn{5}{|c|}{ Vincristine $(\mu \mathrm{g} / \mathrm{ml})$ : } \\
\hline 0 & M̆KN45 & $72(3 \%)$ & $67(5 \%)$ & $63(2 \%)$ \\
\hline $0 \cdot 1$ & " & $63(6 \%)$ & $69(5 \%)$ & $60(0 \%)$ \\
\hline $10 \cdot 0$ & $"$ & $65(4 \%)$ & $57(3 \%)$ & $61(4 \%)$ \\
\hline
\end{tabular}

cell lines. However, there seemed to be a greater sensitivity to shock waves (Table I). MTX failed to have any further effect on either cell line and these data are not included in detail.

ECSW EFFECT ON CELL VIABILITY AND RESPONSE TO CYTOTOXICS

ECSW had no significant effect on either LIM2412 or MKN45 cell viability after 24 hour incubation, however, at 72 hours after treatment, LIM2412 cells showed a $10 \%(\mathrm{p}<0.001)$ decrease in cell viability (Fig 2).

MTX and VCR failed to achieve any additional effect on viability of either cell line after shock wave treatment (data not included). 5-FU increased LIM 2412 cell kill by approximately an additional $10 \%(\mathrm{p}<0.05)$.

EHSW EFFECT ON CELL PROLIFERATION AND RESPONSE TO CYTOTOXIC AGENTS

EHSW had an appreciable effect on both MKN45 and LIM2412 cell proliferation in the presence of 5-FU and VCR (Figs 3 and 4). LIM2412 proliferation seemed to be sensitised to 5-FU and VCR after EHSW treatment. This sensitisation was only observed in cells that had received higher shock wave doses (20 shocks, $\mathrm{p}<0.01$ ).

MKN45 cell proliferation was significantly delayed in the presence of 5-FU $(p<0.001)$ after treatment with $10 \mathrm{EHSW}$, compared with unshocked cells (Fig 5). Unlike LIM2412, MKN45 showed no response to VCR after shock wave treatment.

Inhibition of LIM2412 or MKN45 cell growth was not observed when MTX was present (data not presented).

ECSW EFFECT ON CELL PROLIFERATION AND RESPONSE TO CYTOTOXIC AGENTS

LIM2412 cell growth was unchanged by ECSW and/or exposure to 5-FU, MTX, or VCR.

MKN45 cell proliferation, however, was significantly inhibited after ECSW treatment $(p<0 \cdot 001)$. Figures 6 and 7 show that by treating the cells with either 5-FU or MTX, an increased level of growth inhibition can be achieved $(\mathrm{p}<0.05)$. 
Figure 3: Effect of electrohydraulic shock waves on 5-flourouracil and LIM2412 cell proliferation.

Figure 4: Effect of electrohydraulic shock waves on Vincristine and LIM2412 cell proliferation.

Figure 5: Effect of electrohydraulic shock waves on 5-flourouracil and MKN45 cell proliferation.

Figure 6: Effect of extracorporeal shock waves on methotrexate and MKN45 cell proliferation.

Figure 7: Effect of extracorporeal shock waves on 5-flourouracil and MKN45 cell proliferation.

\section{Discussion}

Our investigations indicate that in vitro both EHSW and ECSW cause an increase in cell death and decrease in cell proliferation of colonic and gastric cancer cells. This finding is supported by
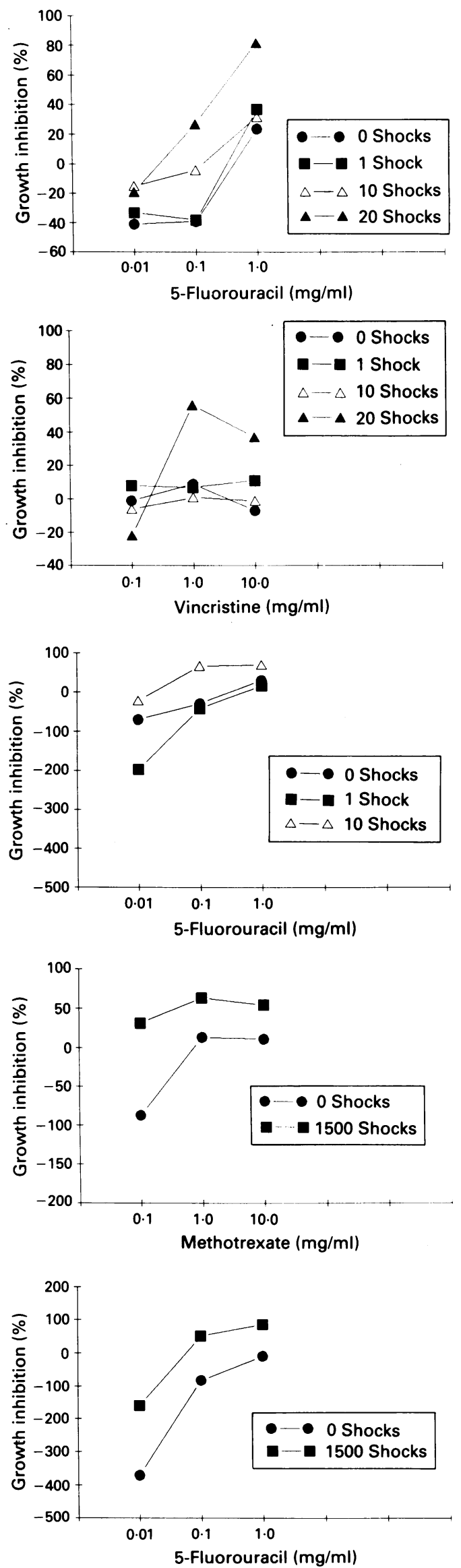

the viability and proliferation studies, which showed a decrease in cell viability and an inhibition of cell proliferation after shock wave treatment. Colonic cancer cells seemed more susceptible to EHSW than gastric cancer cells.

Shock waves have been associated with causing nuclear membrane and cellular membrane damage and attenuating nuclear chromatin. ${ }^{6}$ 5-FU acts by altering the RNA of cells, as well as decreasing the surface charge and transmembrane potential of tumour cells. ${ }^{13}$ Our results display an increased response in both LIM 2412 and MKN45 cells to 5-FU toxicity after EHSW and ECSW treatment. This enhancement of sensitivity to 5-FU may be related to the cytological changes in cells after exposure to shock waves, as outlined above. Both colonic and gastric cancer cells' response to 5-FU was greater than responses to either MTX or VCR.

MKN45 cells seemed to be more susceptible to MTX than LIM 2412 cells, whereas VCR exerted a greater cytotoxic effect on LIM 2412 than on MKN45. It is already well established that different cell lines display varying responses to antitumour agents. ${ }^{14}$ There remain many unknowns - the optimal timing of shock waves to chemotherapy and subsequent treatment, the dosage of shock waves and how often this should be repeated.

Preliminary results in the in vitro effect of EHSW and ECSW in colonic and gastric cancer look promising: future work should include in vivo studies. The proposal of sensitising cells to chemotherapy by an accurately applied regional technique clearly could have merit.

We are grateful to CIRCON ACMI for loan of the EHSW equipment and to Dr George Zografos for his helpful advice.

1 NSW Cancer Council Facts. Facts on bowel cancer. Sydney: 1989.

2 Cunliffe WJ, Sugarbaker PH. Gastrointestinal malignancy: rationale for adjuvant therapy using early post operative

3 Murakami A, Koga S, Maeta M. Thermochemosensitivity: augmentation by hyperthermia of cytotoxicity of anticancer drugs against human colorectal tumour clonogenic assay. drugs against human color

4 Silverman RH, Coleman DJ, Lizzi FL, Torpey JH, Driller J Ultrasonic tissue characterisation and histopathology in tumour xenographs following ultrasonically induced hyperthermia. Ultrasound Med Biol 1986; 12: 639-45.

5 Russo P, Stephenson R, Mies C, et al. The effect of extracorporeal shock waves on dunning R3327AT-3 prostate carcinoma. F Urol 1985; 133: 12+A.

6 Randazzo R F, Chaussey CG, Fuchs GJ, Bhuta SM, Lovrekovich $\mathrm{H}$, de Kernion JB. The in vitro and in vivo effects of extracorporeal shock waves on malignant cells. Urol Res extracorporeal shock

7 Berens ME, Welander CE, Griffin AS, McCullough DL Effect of acoustic shock waves on clonogenic growth and drug sensitivity of human tumour cells in vitro. $\mathscr{f}$ Urol 1989 42: $1090-4$

8 Durrant LG, Morris DL. Shock waves increase the sensitivity of human gastric and colorectal cancer cells to cytotoxic chemotherapy. Gut 1990; 31: A596.

9 Holmes RP, Yeaman LI, Li W, et al. The combined effect of shock waves and cisplatin therapy on rat tumours. 7 Urol $1990 ; 144: 159-63$.

10 Brauner A, Brummer F, Hulser DF. Histopathology of shock wave treated tumour cell suspensions and multicell tumour spheriods. Ultrasound Med Biol 1989; 15: 451-60.

11 Hunter PT, Finlayson B, Hirko RJ, et al. Measurement of shock wave pressures used for lithotripsy. $\mathcal{F}$ Urol 1986; 136:

12 Brendal W, Delius M, Goetz A. Effect of shock waves on the microvasculature. Progress in Applied Microcirculation 1987 microvasculature. Progress in Applied Microcirculation 1987,

13 Chabner BA. Pharmacologic principles of cancer treatment. Philadelphia: W B Saunders, 1982.

14 Berens ME, Welander CE, Griffin AS, McCullough DL. High energy shock waves (HESW) inhibit tumour cell proliferation and potentiate efficacy of cytotoxic agents. Proc Ame Urological Assoc, $\mathcal{F}$ Urol 1987; 137: 499A. 